\title{
Analysis of Posture Load of Dining-table Finishing Based on Ergonomics
}

\author{
Jinyuan Nie \\ School of Economics and Management \\ Beijing Jiaotong University \\ Beijing, China
}

\author{
Xinsheng Ke \\ School of Economics and Management \\ Beijing Jiaotong University \\ Beijing, China
}

\begin{abstract}
The purpose of this paper is to analyze and study the situation of reclaiming the work posture load of the staff in the dining hall of Dalian Jiaotong University, and put forward the reasonable improvement measures. The research method adopts the basic industrial engineering process analysis. The present situation of the work load of the canteen staff was analyzed and studied. The conclusion was that the work posture of the canteen staff was unreasonable because the space was unreasonable and the facilities arrangement was not reasonable, the result was that the work posture of the canteen staff was unreasonable, and the work posture of the staff in the canteen was not reasonable, the result was that the work posture of the staff in the canteen was unreasonable. The task is unreasonable, the work table height causes, the canteen staff work posture action level is 3 , the near future domestic demand Improvement. It is necessary to maintain standing posture for a long time because of the professional particularity of dining-table staff. Standing posture for a long time will cause muscle soreness and swelling of lower extremities etc. In order to explore the postural load of dish recovery work, the behavior rules are analyzed. This study adopts basic industrial engineering process analysis, pose evaluation of human factor engineering OWASRULALA REBA, investigation and research method, sensory evaluation method, to analyze and study the present situation of the staff's work load in the canteen.
\end{abstract}

Keywords—plate recovery; process analysis; job analysis; posture evaluation

\section{INTRODUCTION}

With the rapid development of science and technology, the man-machine system becomes more and more complex. The control of some complex systems, even beyond the normal working ability of people, man becomes the main restriction factor in the system, how to reduce the requirements of the system. Or how to improve human ability to adapt to the requirements of the system is a severe challenge of ergonomics.

Since 1970s, with the spread and popularity of electronic computers, in industrialized countries, the number of people using computers has exceeded the integration of any other extreme operator, How to improve the efficiency of humancomputer computer system has become one of the most concentrated and popular contents in ergonomics. At the annual ergonomics conference in the United States, more than $1 / 3$ papers often cover this subject. The main contents of this aspect include: screen display, keyboard, operating system comments, more than the computer work place, the effect of verbal input and output, and so on.

Ergonomics in China started relatively late, but ergonomics developed very rapidly in China. In 1991, the journal Ergonmics published the album of Chinese ergonomics. In 1992, China held the second Pan-Pacific International Conference on Ergonomics and Occupational Safety. But in general, ergonomics is not popularized in our country. Although many people are interested in it, it is quite scattered. The research project is given priority and has little influence on the society.

The importance of ergonomics is closely related to the importance of human beings. At present, because we are overpopulated and under great pressure of employment, people pay very little attention to labor efficiency, so they do not attach importance to ergonomics. This is detrimental to the development of ergonomics in our country, but the living standards of our people are rising rapidly, and people are paying more and more attention to their work and quality of life. This means that people will gradually realize the necessity of ergonomics. In addition, playing is gradually entering the international market. In order to improve the competitiveness of our products, we also need to increase labor efficiency and reduce labor costs. These are the development of human work in our country. Therefore, ergonomics has a broad prospect in China.

Ergonomics focuses on the study of the relationship between human beings, machinery, equipment and the environment, with the aim of achieving health, safety and comfort in productive labor and other activities, while improving working efficiency. For a variety of reasons, it is sometimes necessary for workers to maintain a special position for a long time or to be in a forced physical condition, or for reasons such as excessive work load or excessive rhythm, which may cause injury or illness in certain parts of the body. As a result of pulling, oppressing or friction and so on, can also make certain organs or tissues of the body to produce functional or organic changes, or even form occupational diseases. On the basis of the labor analysis of the work process, a standard is developed to reduce some negative effects on the body caused by the long-term operation of the staff. 


\section{RESEARCH TECHNIQUE}

\section{A. Process Analysis}

Process analysis is to carry out investigation and analysis one by one at each stages of the process, to find out the potential risks, and to find out the factors that lead to the occurrence of the risks. Flow chart refers to the use of some standard symbols to represent certain types of actions, visually describing the specific steps of a working process.

A process approach diagram forms a flowchart series of modules into a sequence of steps or stages of a particular production or business activity, each of which identifies various potential risks factors or risks events, in the process of enterprise risk identification, using the flow chart to draw the business process of business management of the operator of the enterprise can clearly show the key points that have an impact on various activities of the enterprise. Combined with the actual situation of these key points and relevant historical information, the risk situation of the enterprise can be clearly defined.

\section{B. Job Analysis Method}

Activity analysis is to analyze and evaluate the effectiveness and value added of activities through the steps and methods of activity recognition and measurement, resource cost collection and confirmation, cost object consumption activity recognition and measurement, cost cost collection and so on. In order to improve operational efficiency, reduce resource consumption, increase the value of output an analytical method.

\section{OWAS Method[1]}

The OWAS method divided the husband's work posture into four parts: back, arm, leg and load. Each part was coded according to the status of the work posture, and a group of four-digit posture codes could be obtained through the analysis of the work posture. It is used to judge the posture state of the work husband's back, hand, leg and load, and according to these postures, to judge whether the working position of the job is normal or dangerous.

\section{RULA Rapid Evaluation of Upper Limb [2]}

RULA was used mainly for those who worked frequently in the upper extremities. They observed the workers' working posture and evaluated their arms, pencils, wrists, head, arches, and legs with different working posture angles. The possible factors leading to upper limb discomfort were wrist and arm posture, the posture of the whole body, the frequency of joint use, and the upper limb force during the operation.

\section{E. REBA Rapid Systemic Evaluation[3]}

The REBA method is suitable for the work posture of upper and lower extremities when working frequently. Reba divides the body into the torso, head, legs, arms, and body. The six parts of the upper arm and wrist were given different scores according to the different angles of the local working posture, and the torsion or abnormal angle of some parts was added or subtracted.

\section{EMPIRICAL ANALYSIS}

The basic industrial engineering process analysis method was used to analyze the process of plate finishing, to find out the bottleneck action, and then to analyze the bottleneck action by using the posture evaluation method of OWAS, RULA, REBA. Analyze whether improvements are needed. If so, use human engineering methods to improve in many ways.

\section{A. Process Analysis[4]}

TABLE I. PROCESS Flow CHART OF RECYCLING TABLEWARE

\begin{tabular}{|c|c|c|c|c|c|c|}
\hline \multirow{7}{*}{\multicolumn{3}{|c|}{$\begin{array}{l}\text { Work departmen: } \\
\text { Dalian Jiaotong University } \\
\text { canteen } \\
\text { Number: 01-20 } \\
\text { Workname:Plate collector } \\
\text { Begin:December 1st } 2017 \\
\text { Finish:December 30th } 2017 \\
\text { Investigator:Nie Jinyuan } \\
\text { Date:March 12th 2018 }\end{array}$}} & \multicolumn{4}{|l|}{ Statistics } \\
\hline & & & project & $\begin{array}{l}\text { number } \\
\text { of } \\
\text { times }\end{array}$ & $\begin{array}{l}\text { time/ } \\
\mathrm{s}\end{array}$ & $\begin{array}{l}\text { distan } \\
\text { ce/m }\end{array}$ \\
\hline & & & $\begin{array}{l}\text { processi } \\
\text { ng }\end{array}$ & 11 & 41 & \\
\hline & & & $\begin{array}{l}\text { check } \\
\text { up }\end{array}$ & 3 & 3 & \\
\hline & & & carry & 1 & 25 & 20 \\
\hline & & & wait & 1 & 5 & \\
\hline & & & lay in $\nabla$ & 0 & 0 & \\
\hline job instruction & $\begin{array}{l}\text { dist } \\
\text { anc } \\
\mathrm{e} / \mathrm{m}\end{array}$ & $\begin{array}{l}\mathrm{tim} \\
\mathrm{e} / \mathrm{s}\end{array}$ & \multicolumn{3}{|c|}{ Process series } & $\begin{array}{c}\text { remar } \\
\mathrm{ks}\end{array}$ \\
\hline $\begin{array}{l}\text { 1.Reach out } \\
\text { and take the } \\
\text { table plate near } \\
\text { the swill bucket }\end{array}$ & & 3 & & & & \\
\hline $\begin{array}{l}\text { 2.Pour the } \\
\text { leftovers in a } \\
\text { bowl into a } \\
\text { slop bucket }\end{array}$ & & 3 & & & & \\
\hline $\begin{array}{l}\text { 3. Check that } \\
\text { the leftovers in } \\
\text { the bowl are } \\
\text { poured clean }\end{array}$ & & 1 & & & & \\
\hline $\begin{array}{l}\text { 4.Drop the } \\
\text { bowl into the } \\
\text { recycling box }\end{array}$ & & 4 & & & & \\
\hline $\begin{array}{l}\text { 5.Bend over } \\
\text { and put the } \\
\text { spoon and } \\
\text { chopsticks in } \\
\text { the recycling } \\
\text { box }\end{array}$ & & 4 & & & & \\
\hline $\begin{array}{l}\text { 6.Pour the } \\
\text { leftovers from } \\
\text { a plate into a } \\
\text { slop bucket }\end{array}$ & & 3 & & & & \\
\hline $\begin{array}{l}\text { 6.Pour the } \\
\text { leftovers from } \\
\text { a plate into a } \\
\text { slop bucke }\end{array}$ & & 3 & & - & & \\
\hline $\begin{array}{l}\text { 7.Check if the } \\
\text { leftovers in the } \\
\text { dish are } \\
\text { emptied }\end{array}$ & & 1 & & & & \\
\hline
\end{tabular}




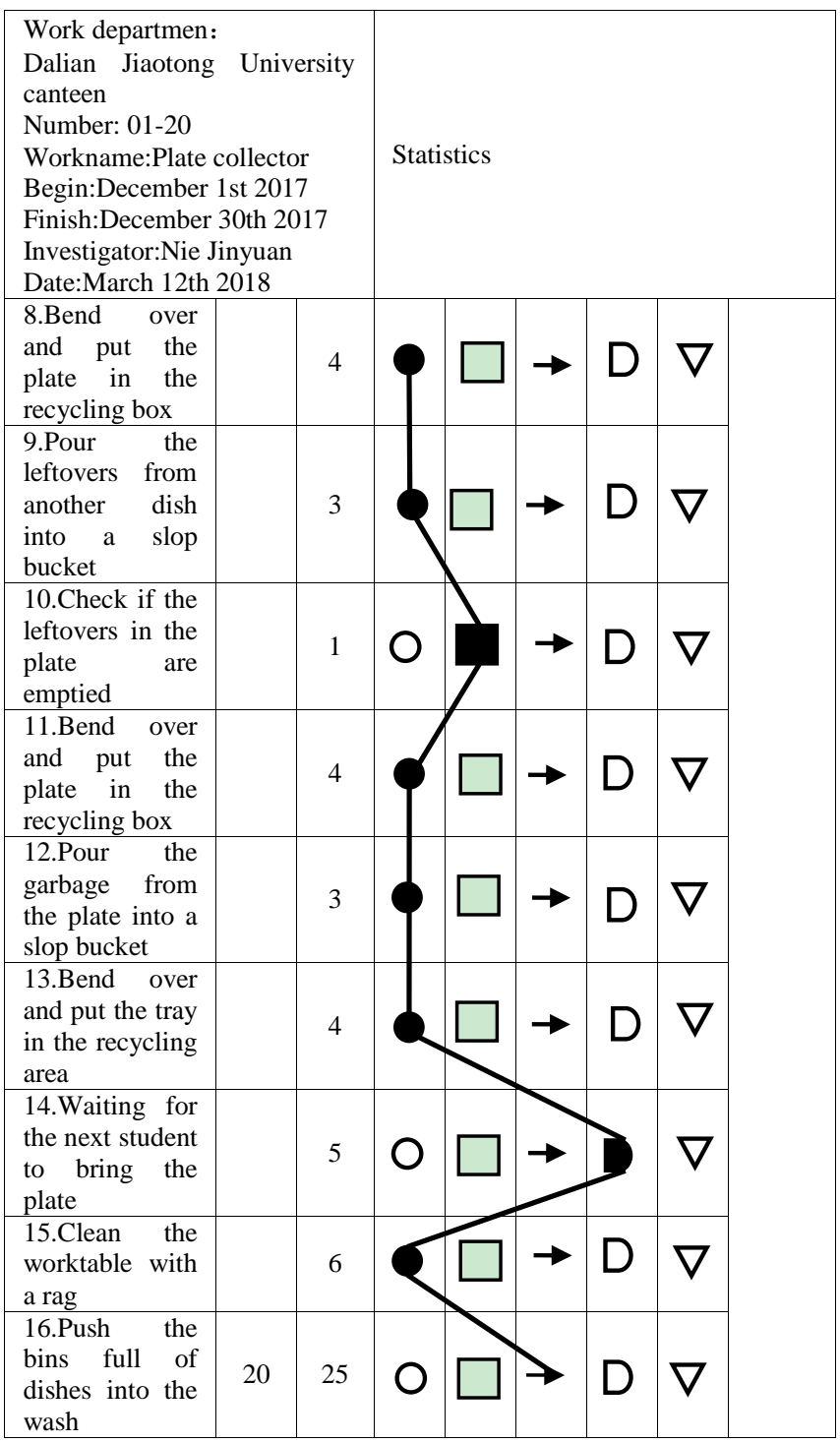

Through the analysis of time data, it can be found that the behavior with bending action is a bottleneck action because of its long working time, heavy labor load and complex movement.

\section{B. Job Analysis [5]}

The "job decomposition" column divides the work into 19 steps in detail. When observing the time required for each step, some operations are difficult to observe accurately with a stopwatch because the time is too short. The breakdown of the elements of excessive combination, divided into five units of operation.
TABLE II. OPERATION ANALYSIS OF RECYCLING TABLEWARE

\begin{tabular}{|c|c|c|c|}
\hline \multicolumn{2}{|c|}{ job analysis } & \multirow{2}{*}{$\begin{array}{c}\text { Operation } \\
\text { unit }\end{array}$} & \multirow{2}{*}{$\begin{array}{c}\text { observati } \\
\text { on point }\end{array}$} \\
\hline the left hand & the right hand & & \\
\hline $\begin{array}{l}\text { 1) reach out and } \\
\text { move the cutlery } \\
\text { near the slop bucket }\end{array}$ & $\begin{array}{l}\text { 1) reach out and } \\
\text { move the cutlery } \\
\text { near the slop } \\
\text { bucket }\end{array}$ & $\begin{array}{l}\text { 1) position } \\
\text { of } \\
\text { tableware }\end{array}$ & $\begin{array}{l}\text { The } \\
\text { moment } \\
\text { the hand } \\
\text { began to } \\
\text { reach for } \\
\text { the cutlery }\end{array}$ \\
\hline 2) take the bowl & $\begin{array}{l}\text { 2) hold chopsticks } \\
\text { and spoons }\end{array}$ & \multirow{7}{*}{$\begin{array}{l}\text { 2) } \\
\text { Recycling } \\
\text { bowls and } \\
\text { chopsticks }\end{array}$} & \multirow{7}{*}{$\begin{array}{l}\text { The } \\
\text { moment } \\
\text { my hand } \\
\text { began to } \\
\text { reach for } \\
\text { the bowl } \\
\text { and } \\
\text { chopsticks }\end{array}$} \\
\hline $\begin{array}{l}\text { 3) move above the } \\
\text { swill bucket }\end{array}$ & $\begin{array}{l}\text { 3) move above the } \\
\text { swill bucket }\end{array}$ & & \\
\hline 4) holding & $\begin{array}{l}\text { 4) scraping the } \\
\text { leftover food in a } \\
\text { bowl } \\
\text { chopsticks }\end{array}$ & & \\
\hline 5) holding & $\begin{array}{l}\text { 5) move to Recycle } \\
\text { Box }\end{array}$ & & \\
\hline 6) holding & $\begin{array}{l}\text { 6) put into the } \\
\text { recycling box }\end{array}$ & & \\
\hline $\begin{array}{l}\text { 7) move to Recycle } \\
\text { Box }\end{array}$ & 7) idle & & \\
\hline 8) put the bowl away & 8) idle & & \\
\hline 9) reach for the plate & $\begin{array}{l}\text { 9) reach for the } \\
\text { plate }\end{array}$ & \multirow{5}{*}{$\begin{array}{l}\text { 3) } \\
\text { Recycling } \\
\text { plates }\end{array}$} & \multirow{5}{*}{$\begin{array}{l}\text { The } \\
\text { moment } \\
\text { the hand } \\
\text { began to } \\
\text { reach to } \\
\text { the plate }\end{array}$} \\
\hline $\begin{array}{l}\text { 10) move above the } \\
\text { swill bucket }\end{array}$ & $\begin{array}{l}\text { 10) move above } \\
\text { the swill bucket }\end{array}$ & & \\
\hline $\begin{array}{l}\text { 11) dumping of } \\
\text { residual food }\end{array}$ & $\begin{array}{l}\text { 11) dumping of } \\
\text { residual food }\end{array}$ & & \\
\hline $\begin{array}{l}\text { 12) move to Recycle } \\
\text { Box }\end{array}$ & $\begin{array}{l}\text { 12) move to } \\
\text { Recycle Box }\end{array}$ & & \\
\hline 13) place the dishes & $\begin{array}{l}\text { 13) place the } \\
\text { dishes }\end{array}$ & & \\
\hline $\begin{array}{l}\text { 14) reach for the } \\
\text { plate }\end{array}$ & $\begin{array}{l}\text { 14) reach for the } \\
\text { plate }\end{array}$ & \multirow{5}{*}{$\begin{array}{l}\text { 4) } \\
\text { Recycling } \\
\text { plates }\end{array}$} & \multirow{5}{*}{$\begin{array}{l}\text { The } \\
\text { moment } \\
\text { the hand } \\
\text { began to } \\
\text { reach to } \\
\text { the plate }\end{array}$} \\
\hline $\begin{array}{l}\text { 15)Move to the top } \\
\text { of the slop bucket }\end{array}$ & $\begin{array}{l}\text { 15)Move to the top } \\
\text { of the slop bucket }\end{array}$ & & \\
\hline $\begin{array}{l}\text { 16)Throw off } \\
\text { sundries }\end{array}$ & $\begin{array}{l}\text { 16)Throw off } \\
\text { sundries }\end{array}$ & & \\
\hline $\begin{array}{l}\text { 17)Move to recycle } \\
\text { box }\end{array}$ & $\begin{array}{l}\text { 17)Move } \\
\text { recycle box }\end{array}$ & & \\
\hline $\begin{array}{l}\text { 18)Put the plate } \\
\text { away. }\end{array}$ & $\begin{array}{l}\text { 18)Put the plate } \\
\text { away. }\end{array}$ & & \\
\hline 19)Clean the table & 19)Clean the table & $\begin{array}{l}\text { 5) } \\
\text { cleaning }\end{array}$ & $\begin{array}{c}\text { The } \\
\text { moment } \\
\text { you hold a } \\
\text { towel }\end{array}$ \\
\hline
\end{tabular}

From the work analysis table, we know that in the second, third, and fourth operating units, the labor time required is more, the labor load is large, and the actions are complex. And all three operation units need to reach out and put the tableware in a fixed position. And because the worktable is not arranged properly, as shown in "Fig. 1", the two tables are too scattered and far apart. Increased the movement distance of the staff. The dishware recycling area, the tray recycling area and the box for spoon chopsticks were placed on one side, causing the placement to pile up. Wasted the other side of the space resources. And in reaching for cutlery, but also involving the legs and waist and other parts of the hard cooperation, because this is more likely to lead to labor fatigue.

Through the analysis of two methods of basic industrial engineering, it is determined that the action of bending and twisting the cutlery at the same time is the bottleneck action. 


\section{OWAS Posture Evaluation}

Back: 4 bending and twisting

Upper limb: 1 arms lower than shoulder

Lower limb: 2 feet standing

Load $1<5 \mathrm{~kg}$

Pose code: 4121

\section{Action level: AC2}

$\mathrm{AC} 2$ poses with minor injuries and needs to be improved in the near future.

\section{RULA Posture Evaluation}

Arm posture-forward tilt 45-90, score 3; forearm posture-060. 0 , score 2 , plus forearm expansion, score 3 ; wrist positiondown less than 15., wrist lateral turn, score 3; twist angle smaller, score 1; The total score of A was 4 points. The muscle state score was 1 because the staff member's movements were repeated more than four times a minute, and the load score was 1 score for 2-10 kg intermittent load, and 1 score for Score C6.

Neck posture-lean forward 0-10.0, score 1; body posturelean forward 20-60. 0, and body torsion, score 4; legs standing steadily, score 1; check table B: 5 . Score D5.

According to the Score C and Score D tables, the total score of RULA is 6, and the level of action is 1 : AL3, which indicates that it is necessary to further investigate and improve the working posture in recent days.

\section{E. REBA Posture Evaluation}

Body posture -- forward 20-60., and body twist, scored 4 points; neck posture --0-20., scored 1 points; leg posture, legs were weighed, knees bent 30-60 degrees, scored 2 points, body size, neck and leg scores were 3 points, the load was less than $5 \mathrm{~kg}$, and the total score of A was 5 points.

Arm posture-forward tilt 45-90, score 3; forearm pose 0-60. 0 , score 2; wrist pose-downward 15.15. Wrist twisting, score 2; check the table for arm, forearm, wrist, total score 5, hand holding tableware acceptable, The score is 1 and the total score of $B$ is 6 .

The total score of REBA is 8 and the level of action is 3 , which indicates that the risk level is high and the posture should be improved as soon as possible.

Through the analysis and evaluation of three kinds of postures, it is concluded that the posture is unreasonable and easy to cause the musculoskeletal injury of the workers. The main causes are the bending and torsion of the waist, the forward or backward tilt of the neck, the extension of the hand, the torsion of the wrist, etc. If we avoid these problems in the project of operation, we need to improve them.

\section{F. Improved Method}

Canteen staff now needs to recycle bowls, chopsticks, garbage, dishes, plates, spoons. There are too many recycling tasks. And the space is too far away.
Effective ergonomic design can reduce the musculoskeletal damage of the workstation. In order to achieve the design goal, the main dimensions of the worktable should be determined by using anthropometric data according to the nature of the task. First of all, determine the human body size of the target user. In general, the more comfortable working height is $5-10 \mathrm{~cm}$ higher than the elbow height while standing. The average elbow height of women standing in our country is $96 \mathrm{~cm}$. So for women who stand between 86 and 91 centimeters, the working height should be 92-97 centimeters. However, the height of the work table is related to the nature of the work.

Through the layout and flow chart, we can see that the two tables are too scattered and the relative distance is too far, which increases the moving distance of the staff. The bins, dishes and containers in the recycling area of the dinner plate are all placed on one side, resulting in the stacking of the placement position. Waste the other side of the space resources. Flow, because the staff uses one hand too much, causes the other hand to be idle for a long time, greatly limit the improvement of work, reduce the work efficiency.

In order to make full use of space resources and the coordination and cooperation of both hands, we put the table together and try to make it a fan shape, making it easier for both hands to get the tableware. Reduce movement distance. Place trash bin and dishware recycling area to the left of the staff, place the chopstick spoon recycling area on the right side, and appropriately increase the height of the recycling bin to reduce the bending degree.

The ECRS principle was used to analyze the process before improvement: one of the steps 7 and 10 above was cancelled; the fifth step was cancelled because the spoon chopsticks were handled by the students themselves; and the two plates were operated with both hands. Steps 6 and 9 above can be combined. The previous tedious steps are sorted out. The recycling order is rearranged. The dishes and dishes are packed first, and the dishes are finally packed. By reducing the work tasks, we cancel the spoons. Chopstick movements. Due to venue rearrangement and platform height adjustment, bending and twisting will be reduced.

\section{Conclusion}

In order to improve the working efficiency and ensure the safety and health of the workers, this paper focuses on the study of the workload of the dining room staff in the dining room of Dalian Jiaotong University graduate school, in order to improve the irrationality of the work process and ensure the safety and health of the workers. Through this study, we found that the workload gap between the left and the right in the normal work of employees is large, and in the long run, it will inevitably lead to some pain in the wrists, pain in the waist, etc., and the dishware and lunch box recycling section of the staff has been put aside. It causes waste of resources on the other side. In the long run, the efficiency of employees cannot be improved, and it is easy to cause occupational diseases. Based on this, the proposal of this paper is to place two chopsticks baskets in front of the staff table, one for students to throw chopsticks, the other for throwing spoons, this can reduce the work tasks of employees, fundamentally reduce the workload 
of employees; Second, if conditions permit, the workbench can be set to a fan workbench, so that the employee's hand movement distance will be reduced, the opponent's load will be reduced, and the workbench height can be reduced or increased appropriately. According to the principle of raising the height of the staff elbow by about 6 centimeters, as this is the most comfortable position of the staff; finally, the garbage can be separated from the dishware recycling area of the staff Placement, so that the ground resources are fully utilized, and the workload of the left and right hand is equal, so it will not cause one-handed fatigue.

\section{REFERENCES}

[1] M. Arip Wahyudi, Wike A.P. Dania, Rizky L.R. Silalahi, "Work Posture Analysis of Manual Material Handling Using OWAS Method," Agriculture and Agricultural Science Procedia, vol. 3, January 2015,pp. 195-199.

[2] Sara Dockrell, Eleanor O'Grady, Kathleen Bennett, Clare Mullarkey, Rachel Mc Connell, Rachel Ruddy, Seamus Twomey, Colleen Flannery,"An investigation of the reliability of Rapid Upper Limb Assessment (RULA) as a method of assessment of children's computing posture," Applied Ergonomics, vol. 43,September 2011, pp.632-636.

[3] Sue Hignett, Lynn McAtamney, "Rapid Entire Body Assessment (REBA)," Applied Ergonomics, vol. 31, 2000, pp. 201-205.

[4] Paul Baybutt, "Cognitive biases in process hazard analysis," Journal of Loss Prevention in the Process Industries, Vol 43,2016, pp. 372-377.

[5] Heiner Dunckel, "Job Analysis and Work Roles," International Encyclopedia of the Social \& Behavioral Sciences (Second Edition), 2015,pp 811-815. 